\title{
Yoga is A Lifestyle
}

\author{
Figen Yaman Lesinger and Cevdet Tinazci* \\ Faculty of Sport Sciences, Near East University, Cyprus
}

Submission: October 10, 2019; Published: December 04, 2019

*Corresponding author: Cevdet Tinazci, Faculty of Sport Sciences, Near East Unıversity, Cyprus

\begin{abstract}
Seen in recent years, that is, industrialization, technological and production started with the technology faster and faster as the integration of the means of production as a result of our activities of daily living and requirements of our movement, the rate has fallen, and the improved access and decreased rate of physical activity in people's daily life level. Working life has an important place in the life of man. Working people not just survive, but actually what they're doing, be happy, be satisfied, have positive attitudes and to use that knowledge and capability for work gives meaning to life is also extremely important.

The study not only living the quality of working conditions, the sensitivity of the work environment, but also the individual can improve himself, to get away from stress, to feel good about yourself for it is just as important. In this context, the work description, job satisfaction, job stress and job attitude concepts are explained. One of the most serious problems that affects individual employee stress. Not being aware lays stress on the basis of many problems Zorba [1]. The human brain when faced with any stress factor, you can resist, or may show signs of exhaustion. In business especially, excessive workload, organizational factors and the nature of work can be various. On the other hand, there are also other individual differences in the meaning of the human stress factor. Several individuals that have been developed in order to stress control method.
\end{abstract}

Keywords: Human brain, Stress control method, Physical activity, Yoga is a lifestyle, Human stress, Sickness and death, Protection of Health, Sivananda yoga, Breathing exercises, Hypersensitivity

\section{Introduction}

Individuals socio-cultural differences from the perspective of the development level of countries, the level of availability of the means of production caused a decrease in the level of physical activity in individuals and the self continues. The decrease of physical activity in different communities leads to the increase in health problems also individuals. Several studies examined the level of physical activity between individuals according to age group 35-44 age group and the level of physical activity is highest in the age group 15-19 and the lowest level followed, it was determined that this group is a group of individuals over the age of 55. Individuals with high levels of income, low-income individuals were more active than when they are removed from the results. In terms of occupational groups, students have a $72 \%$ rate the most inactive group Nagarathna \& Nageranda [2,3].

Physical activity in individuals only, apart from the Prevention of chronic diseases, neuromotor activity skills, balance and coordination, improves functional capacity, activity, and neurological, cognitive, provides for the protection of Health. The main factors that cause sickness and death in past years in research; personal and environmental hygiene, access to clean water, inadequate and poor nutrition, unhealthy living conditions today, while cardiovascular diseases, various types of cancer, physical inactivity, obesity, and tobacco use are. When considering the benefits of exercise, individuals exercise behavior for the development of comprehensive, sustainable, there is a need for regional and global policies Nagarathna \& Nageranda $[2,3]$. The above-mentioned reasons, the age of Technology individuals are now, despite those increasing levels of physical activity and diseases with the goal of providing degrees to be thrown backwards, often the first individuals prefer to relax psychologically. Psychological relaxation yoga, which is one of the methods of humanity starting from that day, realize the power of the individual as a doctrine of human nature it is a thriving spiritual Nagarathna \& Nagradna [2,3].

Yoga, mind, body and spirit by doing a trio of studies on the awareness of this is the technique of improving communication. The effect on others of the change that occurred in one of these three structures, focusing on my attempts to correct adversely affected. Mind, Body, Spirit yoga for the strengthening of its interaction with each other, the trio practiced technique, helps to explain the existence of. Practice makes berraklastirara integration with the real nature of the body and the mind. It is 
not enough only to know that we were there. We need to deepen existential issues. Yoga techniques focus on achieving this deepening (The Sivananda Yoga Vedanta Center, 2003).

It is a method of focusing and meditation that helps to control emotional state by preventing emotional hypersensitivity with the teaching of clarification of emotions Nagarathna \& Nagrand $[2,3]$. Yoga techniques, asanas, and meditation in the name of the work contains three basic pranayakala. Asanas, improve balance, flexibility and coordination that occur from specialized positions are made for the purpose of enhancing physical exercises. Asana (Posture) exercises and force the muscles to increase relaxion Nov, to increase joint mobility, and protection, ensuring correct posture, helps to organize the respiratory, cardiovascular, digestive, and have positive effects on the endocrine system. I pranayakala, the awareness of the body with controlled breathing focuses on breathing exercises that are specialized. Pranayama (breathing) exercises, contribute to the integration of body and mind, regulates breathing, increases breath awareness, breathing-export activity, conscious and nonconscious, nervous pathways based on the idea of achieving, pranayama (breathing) exercises builds bridges between the body and the mind. The domain your breath on your body (muscles, joints, internal organs) taken into consideration; the idea that breathing plays a key role between the body and the mind activity has been suggested Oken [4]. If you meditate, the thoughts of the individual focusing on it intentionally; attention, awareness, and aims to enhance the power of perception is a mental process. The human mind has calmed down, as too much reduces the negative effects of stress. By maintaining balance in emotions, increases the ability to cope with problems faced by people Nagarathna \& Nagrand $[2,3]$.

The technique of Yoga, a physical activity, in addition to being making a positive contribution to people's mental and psychological. Thus, yoga can improve the quality of one's life. Tips removed, and a workout besides being specialized in the subject technique, the individual's self-perceptions of competence and self is effective on. Deep and complete relaxation of the body as a whole with the execution of yoga philosophy, breath control, maturity of mind, to increase awareness, the creation of a state of complete satisfaction, balance, and coordination allows for the development of. The study of yoga in which the target individual's self-awareness of the creation and development of life satisfaction and happiness by increasing the ability to distinguish a state of strengthening is to contribute to the development Williams \& Petronis [5].

Breathing techniques (pranayama) and posture work (asana) of yoga, healthy individuals from the group in addition to be a therapeutic disease, children, pregnant women, the elderly have been used by specific groups, such as. Nov yoga exercises that enhances body awareness by focusing on different groups of; fibromyalgia, osteoarthritis, carpal tunnel syndrome, multiple sclerosis, chronic pain, drug addiction, and depression that is being used to treat many diseases such as irritable bowel syndrome personal development is one of the oldest known methods Williams \& Petronis [5]. In recent years, is used as a method in cancer patients to help with treatment in Kalim and right. Yoga therapy; special equipment due to low levels of be done without the need and risk for different diseases and age groups can be easily applied to Smith \& Pukall $[6,7]$.

Future generations acquiring the habit of physical activity in order to increase the level of sport in childhood is very important. Depends about how family involvement in children the sport of sports activities is. For this reason, training is the place where the sport is given as the habit of the first of the family which is very important. After-school and family collaboration, the children should be encouraged to participate in sports activities. According to studies, a child's participate in sports activities if the child is willing, as much as the promotion of the family is also important. Family socio-economic level increases, the rate of children participation in sport is increasing Dinç [8]. As a result, stress is actually one of the biggest problems working individuals. The human brain when faced with any stress factor, you can resist, or may show signs of exhaustion. The individual's sources of stress in business life and away from this disease or to reassure himself in order to eliminate various factors, can be placed into the yoga lifestyle. Yoga reducing stress, enhancing life satisfaction, mental health etc protective and curative treatment of the diseases by considering the properties of the process being used can be used as supportive treatment. Positive effects of yoga on stress, especially psychological well-being, that may be a good technique suggest. In this direction, made the necessary incentives for the dissemination of the practice of yoga may also be recommended.

\section{References}

1. Zorba E (2009) Herkes İçin Yaşam Boyu Spor. Nehir Yayınları, Ankara, p. 67-69.

2. Nagarathna R, Nageranda HR (2007) Integrated Approach of Yoga Therapy for Positive Health, Bangalore: Swami Vivekananda Yoga Prakashana, pp. 390-542.

3. Nagarathna R, Nageranda HR (2007) Integrated Approach of Yoga Therapy for Positive Health Bangalore: Swami Vivekananda Yoga Prakashana, pp. 976-1085.

4. Oken BS, Zajdel D, Kishiyama S, Flegal K (2006) Randomized, controlled, six-month trial of yoga in healthy seniors: effects on cognition and quality of life. Altern Ther Health Med 12(1): 40-47.

5. Williams KA, Petronis J (2005) Effect of Iyengar yoga therapy for chronic low back pain. Pain 115(1-2): 107-117.

6. Smith KB, Pukall CF (2009) An evidence-based review of yoga as a complementary intervention for patients with cancer. Psychooncology 18(5): 465-475.

7. (2003) The Sivenanda Yoga Vedanta Center. Meditation. Published by Simon \& Schuster, New York, USA, pp. 644-980.

8. Dinç Z (2011) Ailelerin Çocuklarını Spor ve Fiziksel Aktiviteye Yönlendirmelerine İlişkin Görüşleri. E Journal of New World Sciences Academy p. 25-88. 
(C) (1) This work is licensed under Creative BY DOI: 10.19080/JYP.2019.08.555739
Your next submission with Juniper Publishers will reach you the below assets

- Quality Editorial service

- Swift Peer Review

- Reprints availability

- E-prints Service

- Manuscript Podcast for convenient understanding

- Global attainment for your research

- Manuscript accessibility in different formats ( Pdf, E-pub, Full Text, Audio)

- Unceasing customer service

Track the below URL for one-step submission

https://juniperpublishers.com/online-submission.php 